\title{
Jejunal hemorrhage syndrome in a Zebu cow in Brazil
}

\author{
Síndrome de jejuno hemorrágico em gado Zebu no Brasil
}

\author{
Prhiscylla Sadanã Pires $^{\star *}$ Jose Azael Zambrano Uribe ${ }^{\mathrm{II}}$ Antônio Último de Carvalho ${ }^{\mathrm{II}}$ \\ Rodrigo Otávio Silveira Silva ${ }^{\mathrm{I}}$ Felipe Masiero Salvarani ${ }^{\mathrm{II}}$ Rodrigo Melo Meneses ${ }^{\mathrm{II}}$ \\ Luiza Bossi Leite ${ }^{I I}$ Guilherme Guerra Alves ${ }^{I}$ Luciana Aramuni Gonçalves ${ }^{I}$ \\ Francisco Carlos Faria Lobato ${ }^{\mathrm{I}}$ Elias Jorge Facury Filho ${ }^{\mathrm{II}}$
}

\section{ABSTRACT}

Clostridium perfringens type A has been incriminated as the etiologic agent in jejunal hemorrhage syndrome (JHS), which is a disease that affects dairy cattle. Although this microorganism is considered an important enteropathogen the pathogenesis of JHS is still not clear, and there have been no reports of its occurrence in Brazil so far. The aim of this study was to describe the occurrence of JHS by infection with a $\boldsymbol{C}$. perfringens type A strain carrying the beta-2 toxin gene in a zebu cow in Brazil, for the first time.
\end{abstract}

- NOTE -
Key words: Clostridium perfringens, beta-2 toxin gene, enteropathogen, enteric blood clot.

\section{RESUMO}

Clostridium perfringens tipo A tem sido considerado agente etiológico da síndrome do jejuno hemorrágico (SJH), que é uma doença que afeta comumente os rebanhos de gado. Embora este microrganismo seja considerado um importante enteropatógeno, a patogênese da SJH ainda não foi elucidada, e não havia sido reportada no Brasil até então. O alvo deste estudo foi descrever pela primeira vez a ocorrência da SJH causada por C. perfringens tipo $A$, carreador do gene da toxina beta-2, em um zebuíno no Brasil.

Palavras-chave: Clostridium perfringens, gene da toxina beta-2, enteropatógenos, coágulo sanguíneo entérico.

A 33-month-old Gir, from a dairy farm located in Bom Despacho, MG, was treated at the Veterinary Hospital. The cow was in lactation for approximately 120 days, with an average of $55 \mathrm{lb} /$ day. It was being fed with $26 \mathrm{lb} /$ day of a concentrate (16\% of protein, corn silage, hay), mineral supplement and ad libitum water. The cow presented apathy, a sudden reduction in milk production and dark, sparse and soft stools.

The bovine was subjected to a physical examination, hemogasometry, routine hematology and serum biochemistry. Peritoneal fluid samples were collected to physical and cytological analyses. The animal remained in Hospital Veterinário of Universidade Federal de Minas Gerais (HV-UFMG) for a day, receiving fluidotherapy. With suspicion of bowel obstruction, an exploratory laparotomy was conducted.

Necropsy was performed immediately after death, and intestinal content was collected and sent to the Anaerobes Laboratory- UFMG. The anaerobe bacteriology were performed (SILVA et al., 2013) and characteristic $C$. perfringens colonies were subjected to multiplex (VIEIRA et al., 2008) and netB (necrotic enteritis B-like toxin) PCR (KEYBURN et al., 2008). Upon physical examination, apathy, bloating, colic, tachypnea (64 breaths $\mathrm{min}^{-1}$ ), tachycardia (90 heartbeats $\left.\mathrm{min}^{-1}\right)$, ruminal atony, and congested ocular and episcleral mucosa vessels were observed. Stools in small quantities with abundant mucus were observed at rectal palpation, they were dark-colored and had a foul odor.

'Laboratório de Anaeróbios, Escola de Veterinária, Universidade Federal de Minas Gerais (UFMG), Av. Antônio Carlos, 6627, 31270-901, Belo Horizonte, MG, Brasil. E-mail: prisadana.ufmg@hotmail.com. "Corresponding author.

IIClínica de Ruminantes, Escola de Veterinária, UFMG, Belo Horizonte, MG, Brasil.

IIINúcleo de Ciências Agrárias e Desenvolvimento Rural, Programa de Pós-graduação em Ciência Animal, Universidade Federal do Pará (UFPA), Campus Universitário do Guamá, Belém, PA, Brazil. 
Upon cell blood count, an increase in white blood cells (19.400 cells $\left.\mu \mathrm{L}^{-1}\right)$ accompanied by an increase in the concentration of metamyelocytes (194 cells $\left.\mu \mathrm{L}^{-1}\right)$, rods $\left(1.164\right.$ cells $\left.\mu \mathrm{L}^{-1}\right)$, segmented cells (12.416 cells $\left.\mu \mathrm{L}^{-1}\right)$ and the neutrophil/lymphocyte rate (2.53), featuring a neutrophilic leukocytosis with a left nuclear shift of regenerative-type cells.

Serum biochemistry showed elevated in alanine aminotransferase (ALT-84U L $\mathrm{L}^{-1}$ ) and gammaglutamyltransferase (GGT-65.9U L $\left.\mathrm{L}^{-1}\right)$. The peritoneal fluid was turbid, red and with cytologic predominance of mononuclear and neutrophil cells, which featured an exudate outpouring.

The venous blood gas analysis revealed a high $\mathrm{pH}$ (7.5), a base excess of $15 \mathrm{mmol} \mathrm{L}^{-1}$, an $\mathrm{HCO}_{3}^{-}$concentration of $38.1 \mathrm{mEq} \mathrm{L}^{-1}$ and a $\mathrm{pCO}_{2}$ of $79 \mathrm{mmHg}$. This indicated metabolic alkalosis with compensatory respiratory acidosis. Additionally, the potassium and chloride concentrations were low, with values of 3.8 and $87 \mathrm{mmol} \mathrm{L}^{-1}$, respectively.

During the exploratory laparotomy, a stretched and diffuse congested small intestine was observed. Death occurred 96h after onset of the clinical signs. At necropsy, the abomasal mucosa was edematous, hyperemic with multifocal to coalescing linear ulcers (Figure 1A).

The mucosa and serosa of the jejunum were intense and diffusely distended, swollen and had a dark red color (Figure 1B). There was an intraluminal blood clot and in its attached area, the mucosa was liquefied and covered by a dark red liquid. It featured a diffuse, necro-hemorrhagic enteritis associated with the presence of the blood clot (Figure 1C). Six meters after, in the ileum, an intussusception area of $15 \mathrm{~cm}$ was observed, causing complete bowel obstruction. It was characterized by marked edema and congestion

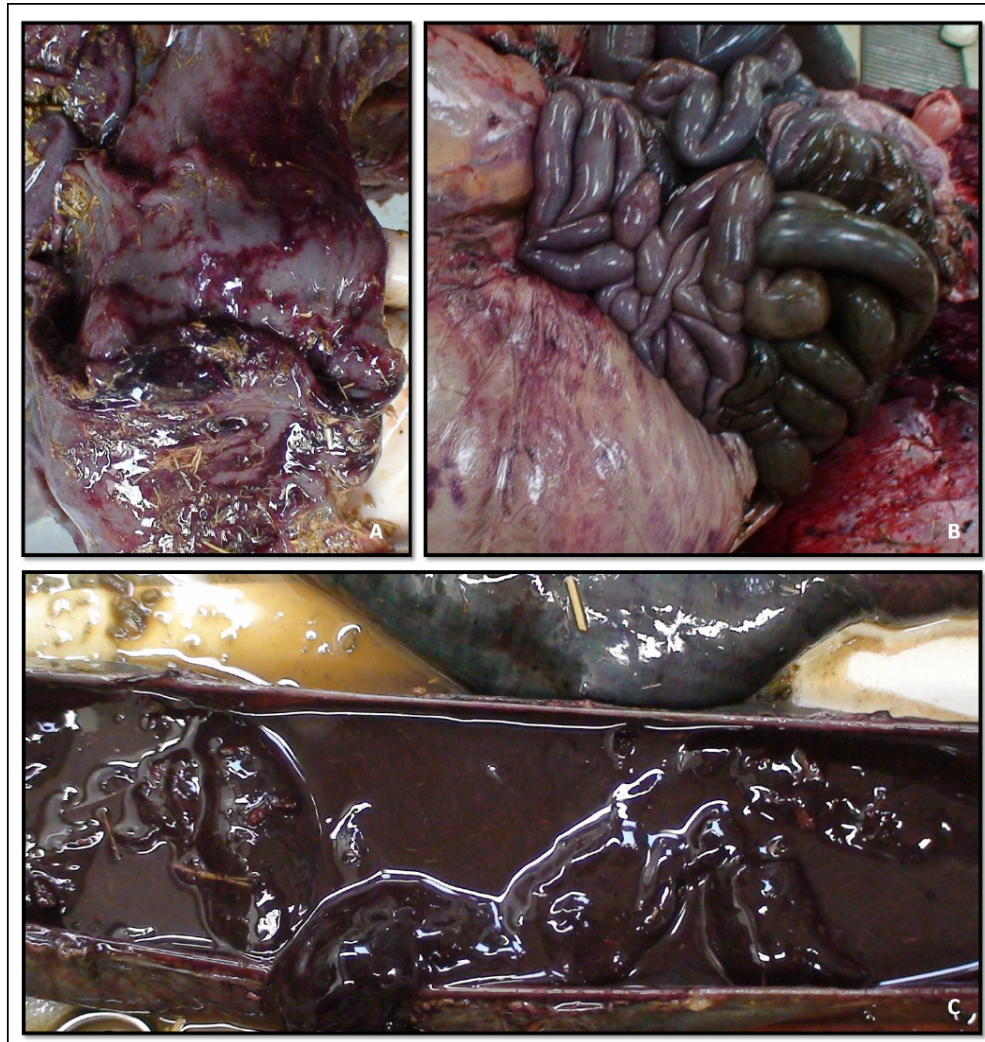

Figure 1 - Gross pathology: cattle; A: abomasum: diffuse mucosal hyperemia, glossy aspect indicating edema, associated with linear erosions with hyperemic borders, presence of blood clots, featuring abomasitis associated with linear ulcers. B: abdominal cavity: small Intestine, diffusely distended, bright and dark red-colored. C: jejunum: serosa and mucosa with intense and diffuse dark red color, edema and necrosis coated with gelatinous dark red material, featuring diffuse necro-hemorrhagic enteritis associated with the presence of blood clots. 
in the serosa of the intestine without necrosis or fibrin in both: in both: intussusceptum portion and intussuscipiens segment.

During the bacteriological examination of the jejunal contents, $\boldsymbol{C}$. perfringens like-colonies were found (almost exclusively) in large quantities. These colonies were genotyped by multiplex PCR as C. perfringens type A positive for the beta- 2 toxin gene $\left(c p b 2^{+}\right)$.

The first JHS report was observed in Holstein Friesian cattle. Sub-mucosal hematomas were observed (ANDERSON, 1991). The disease was called "point source hemorrhage", but the bacteriological were not sufficient to determine its etiology. Later, similar cases were seen in European breeds in different countries (BERGHAUS et al., 2005; TAJIK et al., 2010). Until now, the syndrome had not yet been described in Bos taurus indicus.

This syndrome has also been called jejunal hemorrhage syndrome (ABUTARBUSH, 2002) and hemorrhagic bowel syndrome (TAJIK et al., 2010). ${ }^{0}$ The term JHS is most appropriate, because it reflects the little knowledge about the pathogenesis and characterizes the location of the bleeding.

JHS is a disease of adult cattle and is characterized by acute necrohemorrhagic enteritis with low morbidity and high mortality. $\boldsymbol{C}$. perfringens type $\mathrm{A}$ is often appointed as a causative or potentiating agent of the disease (CECI et al., 2006). However, there is no consensus on the JHS etiology with no successful attempts to reproduce the disease experimentally with strains isolated from clinical natural cases (IVANY et al., 2001).

The five toxigenic types of $\boldsymbol{C}$. perfringens (A-E) are classified according to the production of four major toxins (alpha, beta, epsilon and iota). Although not crucial to toxynotyping, enterotoxin, netB, and beta- 2 toxin are described as additional virulence factors that act synergistically with the major toxins. The involvement of the beta- 2 toxin during occurrences of this syndrome is not well defined, but it was suggested that cpb2 + strains are associated with disease cases, and often culminate in the death of the animals (DENNISON et al., 2002) as we described in the present report. Nevertheless it is necessary more accurate data to associate the gene cpb2 + and severity of disease.

Presently, there is not enough information to determine the risk factors of the disease. Diets based on a high carbohydrate availability and low fiber content allow the passage of undigested food into the small intestine. This environment promotes bacterial multiplication, which results in the release of large amounts of toxins (FACURY FILHO et al., 2009). Bovine that do not consume by grazing are 100 times more likely to present with JHS than animals with some inclusion level (BERGHAUS et al., 2005). In the USA JHS is less frequent in spring seasons in which there is greater pasture availability (GODDEN et al., 2001).

Other risk factors include: high metabolic stress, high-producing dairy cows, lactation stage, excessively large herds and dominant animals (CECI et al., 2006). Although reports in dairy cattle are more common, it is important to emphasize that it can also occur in confined beef cattle, with no gender predisposition in this case (ABUTARBUSH \& RADOSTITS, 2005).

C. perfringens rapidly proliferates after the death of the animal and is considered a frequent invader of carcasses. For this reason, diagnoses based on isolations should be carefully analyzed (CECI et al., 2006). ${ }^{0}$ In this report, the necropsy and sample collection were performed immediately after the animal's death. The profuse and almost exclusive growth of the $\boldsymbol{C}$. perfringens colonies after the bacteriological tests indicates that the agent was present in large amounts and that it may be a rust pathogen.

The most common clinical signs in JHS cases are poor appetite, dehydration, sudden milk production reduction, depression and melena. In some cases, hypothermia, mucous hypochromic, ruminal hypomotility, tachycardia, tachypnea, abdominal distension and pain can be observed in the affected cattle. Upon rectal palpations, distended bowels (jejunum, cecum and colon), a reduction in the amount or absence of feces and the presence of blood clots in the stool are usually observed. (DENNISSON et al., 2002). The clinical findings described in the present report are consistent with those previously reported in the literature, but unfortunately, there are no pathognomonic clinical signs and they often overlap those of other diseases.

The ileal intussusception reported is a very important confounder. The lack of necrosis of the intestinal loop involved in intussusception nor fibrin deposition demonstrate that was an acute process. Probably, the intussusception occurred after occurrence JHS, due to decreased or absent peristaltism of the injured area. This assumption is suported by PEARSON (1971), who reports that distention of intestinal segments, enteritis, alterations in intestinal motility, hypomotility or hypermotility, are considered predisposing factors for the development of intussusception in cattle.

Among the hematological findings, leukocytosis may be explained by the rapid release 
of neutrophils from hematopoietic organs to the site of infection. The increase in liver enzymes (ALT and GGT) can be attributed to the liver damage caused by the circulating toxins that invaded through the intestinal mucosa. Metabolic alkalosis associated with compensatory respiratory acidosis, hypokalemia and hypochloremia are expected due to the extent of bowel obstruction. The functional or mechanical obstruction of the small intestine may have contributed to the the installation of a hypokalemic alkalosis and hypochloremia. Hypokalemia may also have been caused by lack of appetite. The clinical signs reflect the acute nature of JHS and the secondary intestinal stasis (CECI et al., 2006).

In general, animals that develop JHS die within 24 to $36 \mathrm{~h}$ after the onset of clinical signs, and no effective treatments have been described. There is no scientific evidence of the efficacy of vaccination in preventing this syndrome (LEJEUNE, 2004). Prevention is therefore based on providing quality food and an adequate ratio of concentrate and roughage.

Although JHS had not yet been described in Brazil, the association between epidemiological, clinical, gross and bacteriological findings allow for the first firm diagnosis of this syndrome due to $\boldsymbol{C}$. perfringens type $\mathrm{A} c p b 2^{+}$in zebu in the country.

\section{ACKNOWLEDGEMENTS}

This work was supported by funds from Fundação de Amparo à Pesquisa do Estado de Minas Gerais (FAPEMIG), Coordenação de Aperfeiçoamento de Pessoal de Nível Superior (CAPES) and Conselho Nacional de Desenvolvimento Científico e Tecnológico (CNPq). Francisco Carlos Faria Lobato has research fellowship from $\mathrm{CNPq}$

\section{REFERENCES}

ABUTARBUSH, S.M. Jejunal hemorrhage syndrome: a newly emerging disease. Large Animal Veterinary Rounds, v.2, p.16, 2002. Available from: <http://www.islandscholar.ca/ fedora/ repository/ir:ir-batch6-2229>. Accessed: Ago. 30, 2014

ABUTARBUSH, S.M.; RADOSTITS, O.M. Jejunal hemorrhage syndrome in dairy and beef cattle: 11 cases (2001 to 2003). Canadian Veterinary Journal, v.46, p.711-715, 2005 Available from: <http://www.ncbi.nlm.nih.gov/pmc/articles/ PMC1180421/?report =reader>. Accessed: Ago. 30, 2014

ANDERSON, B.C. Point source haemorrhage in cows. Veterinary Record, v.29, p.619-620, 1991. Disponível em: <http:// veterinaryrecord.bmj.com/content/128/26.toc $>$. Accessed: Ago. 30, 2014. doi: 10.1136/vr.128.26.619.

BERGHAUS, R.D. et al. Risk factors associated with haemorrhagic bowel syndrome in dairy cattle. Journal of American Veterinary Medical Association, v.226, p.1700-1706, 2005. Available from: $<$ http://www.cvmbs.colostate.edu/ilm/projects/hbs/2005\%20
JAVMA\%20NAHMS\%20HBS.pdf>. Accessed: Ago. 30, 2014. doi: $10.2460 /$ javma.2005.226.1700.

CECI, L. et al. Hemorragic bowel syndrome in dairy cattle: possible role of Clostridium perfringens type A in the disease complex. Journal of Veterinary Medicine, v.53, p.518-523, 2006. Available from: $<$ http://onlinelibrary.wiley.com/doi/10.1111/ j.1439-0442.2006.00884.x/full>. Accessed: Ago. 30, 2014. doi: 10.1111/j.1439-0442.2006.00884.x.

DENNISSON, A.C. et al. Hemorragic bowel syndrome in dairy cattle: 22 cases (1997-2000). Journal of American Veterinary Medical Association, v.22, p.686-689, 2002. Available from: <http://www.cvmbs.colostate.edu/ILM/projects/hbs/2002\%20 JAVMA\%20HBS\%20Cases.pdf>. Accessed: Ago. 30, 2014. doi: 10.2460/javma.2002.221.686.

FACURY FILHO, E.J. et al. Clinicopathologic features of experimental Clostridium perfringens type D enterotoxemia in cattle. Veterinary Pathology, v.46, n., p.1213-1220, 2009. Available from: $<$ http://vet.sagepub.com/content/46/6/1213.long $>$. Accessed: Ago. 30, 2014. doi: 10.1354/vp.08-VP-0304-U-FL.

GODDEN, S. et al. Survey of Minnesota dairy veterinarians on the occurrence of and potential risk factors for jejunal hemorrhage syndrome in adult dairy cows. The Bovine Practitioner, v.35, p.97-103, 2001

IVANY, J. et al. Determination of the role of Clostridium perfringens type $A$ in intraluminal intestinal hemorrhage syndrome in dairy cows (Abstract). 34 th Annu Conv Proc Am Assoc Bov Pract 2001:145.

KEYBURN, A.L. et al. NetB, a new toxin that is associated with avian necrotic enteritis caused by Clostridium perfringens. PLoS Pathogens, v.4, n.2, p.26, 2008. Available from: <http://www. plospathogens.org/article/info\%3Adoi\%2F 10.1371\%2Fjournal. ppat.0040026>. Accessed: Ago. 30, 2014. doi: 10.1371/journal. ppat.0040026.

LEJEUNE, J.T. Cause of jejunal hemorrhagic syndrome (JHS) still remains enigmatic. Ohio Veterinary Newsletter, v.30, p.3-4, 2004. Available from: <http://vet.osu.edu/assets/pdf/depts/prevMed/ newsletters/OVN2004Summer.pdf>. Accessed: Ago. 30, 2014.

PEARSON, H. Intussusception in cattle. Veterinary Records, v. 89, p. 426-437, 1971. Available from: <http://veterinaryrecord. bmj.com/content/89/16/426>. Accessed: 24/10/2014. doi:10.1136/ vr.89.16.426

SILVA, R.O. et al. Neonatal diarrhea in piglets associated with cpb-2 positive Clostridium perfringens. Brazilian Journal of Veterinary Pathology, v.6, p.94-98, 2013. Available from: $<$ http://www.abpv.vet.br/upload/documentos/DOWNLOADFULL-ARTICLE-05-20881 $2013 \quad 4 \quad 5 \quad 10$ 3.pdf $>$. Accessed: Ago. 30, 2014.

TAJIK, J. et al. Hemorragic bowel syndrome in dairy cattle in Iran: a case report. Iranian Journal of Veterinary, v.11, p.80183, 2010. Available from: <http://www.sid.ir/en/VEWSSID/J pdf/102320103111.pdf $>$. Accessed: Ago. 30, 2014.

VIEIRA, A.A. et al. Genotipagem de Clostridium perfringens isolados de leitões diarreicos. Arquivos do Instituto Biológico, v.5, p.513-516, 2008. Available from: <http://www.biologico. sp.gov.br/docs/arq/v75_4/vieira.pdf>. Accessed: Ago. 30, 2014. 